\title{
AN OBSERVATIONAL STUDY OF AETIOPATHOGENESIS, CLINICAL PROFILES AND MANAGEMENT OF NEONATAL NECROTISING ENTEROCOLITIS
}

\author{
Abhishek Kansal1, Rajiv Jain'2, Suraj Jain ${ }^{3}$, Rishikant Vashishtha ${ }^{4}$ \\ ${ }^{1}$ Assistant Professor, Department of General Surgery, Sri Aurobindo Medical College \& PG Institute, Indore, Madhya Pradesh. \\ ${ }^{2}$ Associate Professor, Department of General Surgery, Sri Aurobindo Medical College \& PG Institute, Indore, Madhya Pradesh. \\ ${ }_{3}^{3}$ Assistant Professor, Department of General Surgery, Sri Aurobindo Medical College \& PG Institute, Indore, Madhya Pradesh. \\ ${ }_{4}^{4}$ Associate Professor, Department of General Surgery, Sri Aurobindo Medical College \& PG Institute, Indore, Madhya Pradesh.
}

\section{ABSTRACT}

\section{BACKGROUND}

Necrotising enterocolitis is the commonest life threatening acquired gastrointestinal emergency of neonates in which lining of the intestinal wall gets necrosed. Although exact aetiology remains obscure, multiple factors like birth asphyxia, prematurity, low birth weight and use of certain drugs have been associated with necrotising enterocolitis.

\section{MATERIALS AND METHODS}

This observational study was carried out on 20 patients of neonatal necrotising enterocolitis in a tertiary care and referral hospital of Indore for a period of two and half years.

\section{RESULTS}

Eighty percent of patients were preterm births with low birth weight. Most of the cases (66\%) presented in the first week of neonatal period. The ileocaecal region was the most common part involved. Necrotising enterocolitis has significantly high mortality rate. In our study, $80 \%$ of cases died due to severe form of disease with associated morbidities.

\section{CONCLUSION}

With this study, we made an attempt to formulate a protocol to make an early diagnosis and to reduce the overall mortality.

\section{KEYWORDS}

Necrotising Enterocolitis (NEC), Low Birth Weight, Prematurity.

HOW TO CITE THIS ARTICLE: Kansal A, Jain R, Jain S, et al. An observational study of aetiopathogenesis, clinical profiles and management of neonatal necrotising enterocolitis. J. Evolution Med. Dent. Sci. 2016;5(100):7388-7393, DOI: $10.14260 /$ jemds/2016/1672

\section{BACKGROUND}

Neonatal necrotising enterocolitis is the commonest life threatening acquired gastrointestinal emergency encountered in neonatal ICU in which the lining of intestine wall gets necrosed. In medical literature, clinical description of the condition matching with necrotising enterocolitis dates back to about two centuries. Siebold (1825), ${ }^{1}$ Simpson $(1838)^{2}$ and Zilher $(1883)^{3}$ were the first few who reported cases suspected to have necrotising enterocolitis. There are few studies in the world literature, which have discussed some or the other parameter about this condition, but there was a need for a comprehensive study to analyse all the factors related to NEC.

The aim of our study was to make a comprehensive review of all the factors related to neonatal NEC and formulate a protocol to make early diagnosis by clinical picture and investigations so that management of these neonates can be improved and mortality can be reduced.

Financial or Other, Competing Interest: None.

Submission 28-10-2016, Peer Review 01-12-2016,

Acceptance 08-12-2016, Published 15-12-2016.

Corresponding Author:

Dr. Rajiv Jain,

\#27, Anand Bagichi,

Agrawal Nagar, Indore,

Madhya Pradesh.

E-mail: drrajivjain16@yahoo.com

DOI: $10.14260 /$ jemds/2016/1672

\section{MATERIALS AND METHODS}

This prospective observational study was carried out between May 2004 to Oct. 2006 in the Department of Surgery, M.G.M. Medical College and M. Y. Group of Hospitals, Indore which is a tertiary care centre of central India.

\section{Inclusion Criteria}

All the patients who were admitted with suspected diagnosis of neonatal necrotising enterocolitis and later on confirmed by diagnostic modalities and/or surgery.

\section{Exclusion Criteria}

1. Patients which did not complete full treatment.

2. Patients who did not give consent to participate in the study.

All the patients included in the study were thoroughly examined and subjected to investigations as per need. The relevant data was recorded in a fixed proforma that included demographic profile, preoperative investigations, intraoperative findings and postoperative followup. At the end of study, the tabulated data on master chart was analysed by simple descriptive statistical method of percentages. Detailed review of literature was done and results of study were compared with other studies. 
RESULTS

Observations

\begin{tabular}{|c|c|c|c|}
\hline Age of Patients & <2 PND & 3-12 PND & >12 PND \\
\hline Number & 8 & 11 & 1 \\
\hline Percentage & 40 & 55 & 05 \\
\hline \multicolumn{3}{|c|}{ Table 1. Age distribution at } \\
presentation (Post-natal day) $\mathbf{N}=\mathbf{2 0}$ \\
\hline
\end{tabular}

The postnatal age at the time of presentation was analysed. Eleven (55\%) out of 20 cases presented at age of 3-12 postnatal days. Eight patients had early onset of disease $(<2$ days), out of which 4 were term and remaining 4 were preterm. [Refer Table No. 1].

\begin{tabular}{|c|c|c|}
\hline Sex of the Patients & Male & Female \\
\hline Number & 11 & 9 \\
\hline Percentage & $55 \%$ & $45 \%$ \\
\hline \multicolumn{2}{|c|}{ Table 2. Sex distribution of cases $\mathbf{N = 2 0}$} \\
\hline
\end{tabular}

Sex distribution of NEC cases was studied and it was found that, out of total 20 patients, 11 were male [55\%] and 9 were female [45\%]. [Refer Table No. 2].

So there was no sex predisposition found in the incidence of NEC.

\begin{tabular}{|c|c|c|c|c|}
\hline $\begin{array}{c}\text { Gestational } \\
\text { Age }\end{array}$ & $\begin{array}{c}\mathbf{4 0} \\
\text { weeks }\end{array}$ & $\begin{array}{c}\mathbf{3 6} \\
\text { weeks }\end{array}$ & $\begin{array}{c}\mathbf{3 4} \\
\text { weeks }\end{array}$ & $\begin{array}{c}\mathbf{3 0} \\
\text { weeks }\end{array}$ \\
\hline $\begin{array}{c}\text { No. of } \\
\text { Patients }\end{array}$ & 04 & 3 & 11 & 2 \\
\hline Percentage & 20 & 15 & 55 & 10 \\
\hline \multicolumn{4}{|c|}{ Table 3. Gestational age of the } \\
patients at the time of birth $\mathbf{N}=\mathbf{2 0}$ \\
\hline
\end{tabular}

Detailed history was taken from the mother regarding actual gestational age at the time of birth and the data regarding gestational age was tabulated [refer Table No. 3]. Out of total 20 patients, only 4 patients have completed 40 weeks' gestational age at the time of birth [Term], rest 16 patients were delivered before completion of full term due to some or the other obstetric indications.

\begin{tabular}{|c|c|c|}
\hline Maturity & Premature & Mature \\
\hline Number of Patients & 16 & 4 \\
\hline Percentage & $80 \%$ & $20 \%$ \\
\hline Table 4. Status of Maturity at Presentation $\mathbf{N = 2 0}$ \\
\hline
\end{tabular}

On assessing the maturity status of the patients by gestational age and other clinical parameters, we found that sixteen patients [80\%] out of 20 were premature at the time of presentation. [Refer Table No. 4].

\begin{tabular}{|c|c|c|c|}
\hline Birth Weight & $\mathbf{1 - 1 . 4 9} \mathbf{~ k g}$ & $\mathbf{1 . 5 - 2} \mathbf{~ k g}$ & $\mathbf{> 2} \mathbf{~ k g}$ \\
\hline No. of Patients & 11 & 5 & 4 \\
\hline Percentage & $55 \%$ & $25 \%$ & $20 \%$ \\
\hline Table 5. Birth Weight Distribution at Presentation $\mathbf{N = 2 0}$ \\
\hline
\end{tabular}

In our study, 11 patients of NEC were of extremely low birth weight, i.e. $<1.49 \mathrm{~kg}$ [55\%]. While 5 patients were of low birth weight i.e. $<2 \mathrm{~kg}[25 \%]$ and only 4 patients were of the birth weight more than $2 \mathrm{~kg}$ [20\%] [Refer Table no. 5].

\begin{tabular}{|c|c|c|}
\hline $\begin{array}{c}\text { Type of } \\
\text { Delivery }\end{array}$ & $\begin{array}{c}\text { Vaginal } \\
\text { Delivery }\end{array}$ & $\begin{array}{c}\text { Caesarean } \\
\text { Section }\end{array}$ \\
\hline No. of Patients & 18 & 2 \\
\hline Percentage & $90 \%$ & $10 \%$ \\
\hline \multicolumn{2}{|r|}{ Table 6. Distribution on the basis } \\
of Mode of Delivery $\mathbf{N}=\mathbf{2 0}$ \\
\hline
\end{tabular}

The mode of delivery was studied and we found that eighteen $(90 \%)$ patients out of 20 were delivered by normal vaginal delivery, while $2(10 \%)$ were born by Caesarean section. [Refer Table No. 6].

\begin{tabular}{|c|c|c|c|c|c|c|}
\hline $\begin{array}{c}\text { Para } \\
\text { meter }\end{array}$ & Pre-maturity & $\begin{array}{c}\text { Low \& Extremely } \\
\text { Low } \\
\text { Birth Weight }\end{array}$ & $\begin{array}{c}\text { Breast } \\
\text { Feeding }\end{array}$ & $\begin{array}{c}\text { Top } \\
\text { Feeding }\end{array}$ & $\begin{array}{c}\text { Birth } \\
\text { asphyxia }\end{array}$ & $\begin{array}{c}\text { Increased } \\
\text { Leucocyte Count }\end{array}$ \\
\hline No. of Cases & 16 & 16 & 16 & 3 & 4 & 4 \\
\hline Percentage & $80 \%$ & $80 \%$ & $80 \%$ & $15 \%$ & $20 \%$ & $20 \%$ \\
\hline \multicolumn{7}{|c|}{ Table 7. Analysis of possible etiological factors of Neonatal NEC } \\
\hline
\end{tabular}

Different possible aetiological factors were studied [Refer Table no. 7]. Prematurity and Low birth weight were found in majority of patients [80\% each]. Enteral feeding was given to 19 (95\%) patients out of 20.16 were breast-fed and 3 were top fed. Birth asphyxia is found in 4 (20\%) out 20 patients. Increased leucocyte count was found in $20 \%$ of patients which suggests infection can be a possible aetiological factor.

\begin{tabular}{|c|c|c|c|c|c|c|}
\hline $\begin{array}{c}\text { Present } \\
\text { ing } \\
\text { Complaints }\end{array}$ & $\begin{array}{c}\text { Abdominal } \\
\text { Disten } \\
\text { tion }\end{array}$ & Vomit-ing & $\begin{array}{c}\text { Regur-gitation } \\
\text { of Feed }\end{array}$ & Obstipa-tion & Melaena & $\begin{array}{c}\text { Poor } \\
\text { Feeding }\end{array}$ \\
\hline Number & 20 & 5 & 1 & 7 & 10 & 18 \\
\hline Percentage & $100 \quad 25$ & 5 & 35 & 50 & 90 \\
\hline \multicolumn{7}{|c|}{ Table 8. Distribution on the basis of clinical presentation } \\
\hline
\end{tabular}

All the patients of NEC presented with complaint of abdominal distension. [Refer Table no. 8]. Half (50\%) of patients had melaena. Eighteen (90\%) patients had history of poor feeding. Other presenting complaints were vomiting, regurgitation and arrest of motion/flatus. 


\begin{tabular}{|c|c|c|c|c|c|c|c|}
\hline Findings & $\begin{array}{c}\text { Abdominal } \\
\text { Distension }\end{array}$ & Tenderness & Rigidity & Guarding & $\begin{array}{c}\text { Visible } \\
\text { Veins }\end{array}$ & Hypothermia & $\begin{array}{c}\text { Ant. Abdomen } \\
\text { Wall Erythema }\end{array}$ \\
\hline Number & 20 & 17 & 14 & 14 & 2 & 7 & 5 \\
\hline Percentage & $100 \%$ & $85 \%$ & $70 \%$ & $70 \%$ & $10 \%$ & $35 \%$ & $25 \%$ \\
\hline \multicolumn{7}{|c}{ Table 9. Abdomen Examination Findings at Presentation } \\
\hline
\end{tabular}

On studying the local examination findings of abdomen [Refer table No. 9], it was observed that the most frequent sign was distended abdomen (100\%). Other clinical signs were tenderness [85\%], rigidity [70\%], guarding [70\%], visible veins over the anterior abdominal wall [10\%] and anterior abdominal wall erythema [25\%]. About 35\% patients had temperature instability in form of hypothermia.

\begin{tabular}{|c|c|c|}
\hline C-reactive protein & Positive & Negative \\
\hline Number & 17 & 03 \\
\hline Percentage & $85 \%$ & $15 \%$ \\
\hline
\end{tabular}

Analysis of $\mathrm{C}$ - reactive protein was done in all the patients of NEC [Refer Table no 10] and it was observed that seventeen out of 20 Patients (85\%) had raised $C$ reactive protein value.

\begin{tabular}{|c|c|c|c|}
\hline Radiological Findings & Persistent Dilated Bowel Loops & Pneumo- peritoneum & Pneumatosis Intestinalis \\
\hline Number & 8 & 7 & 5 \\
\hline Percentage & $40 \%$ & $35 \%$ & $25 \%$ \\
\hline \multicolumn{2}{|c|}{ Table 11. X-Ray of Abdomen } \\
\hline
\end{tabular}

In our study, x-ray of abdomen was done in all the cases. [Refer Table No. 11].

We observed that $40 \%$ of patients had findings of persistent dilated bowel loops in the consecutive $\mathrm{x}$-rays, 35\% showed findings of pneumoperitoneum in their $\mathrm{x}$-rays and $25 \%$ of patients had pneumatosis intestinalis, which is the hallmark of NEC.

\begin{tabular}{|c|c|c|}
\hline $\begin{array}{c}\text { Treatment } \\
\text { Modalities }\end{array}$ & Surgery & Conservative \\
\hline No. of Patients & 11 & 9 \\
\hline Percentage & $55 \%$ & $45 \%$ \\
\hline \multicolumn{2}{|c|}{ Table 12. Treatment Modalities Used $\mathbf{N}=\mathbf{2 0}$} \\
\hline
\end{tabular}

The management of the patients was decided on the basis of clinical and radiological parameters as per the protocol. We observed that 11 patients were managed surgically and 9 patients were managed conservatively. [Refer Table No.12].

\begin{tabular}{|c|c|c|c|c|}
\hline $\begin{array}{c}\text { Gross Pathological } \\
\text { Changes }\end{array}$ & $\begin{array}{c}\text { Gangrenous } \\
\text { Bowel }\end{array}$ & $\begin{array}{c}\text { Perforation } \\
\text { in the Bowel }\end{array}$ & $\begin{array}{c}\text { Oedematous } \\
\text { Bowel }\end{array}$ & $\begin{array}{c}\text { Stricture } \\
\text { in the Bowel }\end{array}$ \\
\hline No. of Patients & 5 & 4 & 1 & 1 \\
\hline Percentage & $45.45 \%$ & $36.36 \%$ & $9.09 \%$ & $9.09 \%$ \\
\hline \multicolumn{7}{r}{ Table 13. Intraoperative Findings of Bowel Involvement $\mathbf{N}=\mathbf{1 1}$} \\
\hline
\end{tabular}

Out of the 20 diagnosed cases of NEC, 11 cases were operated. 2 cases were planned for surgery, but they succumbed before commencement of surgery.

The most common intraoperative finding was gangrenous bowel ( 5 cases) and in 4 cases there were perforations in the bowel. [Refer Table no. 13]. Oedematous bowel and Stricture in the bowel as solitary findings were observed in one case each.

In 11 surgically managed cases, Exploratory Laparotomy was the operation done. Gangrenous bowel was found on exploration in 5 patients, so resection of gangrenous bowel with stoma formation was done.

Perforation in the bowel was found in 4 patients. Among them, 2 patients were managed with resection of perforated segment with anastomosis, 1 patient with primary repair of perforation and stoma formation was done in one patient.

Oedematous bowel was the only finding in 1 patient, so only peritoneal lavage was done. In 1 patient, one stricture was found in the bowel that was smoothly passable, so the bowel was left undisturbed.

Thus, the main surgical procedure was enterostomy in our study that was done in total 6 patients [54.54\%].

\begin{tabular}{|c|c|c|c|c|}
\hline $\begin{array}{c}\text { Bowel } \\
\text { Involved }\end{array}$ & Ileum & Caecum & Jejunum & Colon \\
\hline No. of Patients & 7 & 2 & 1 & 1 \\
\hline Percentage & $63.63 \%$ & $18.18 \%$ & $9.09 \%$ & $9.09 \%$ \\
\hline Table 14. Segment of Bowel Involved N=11 \\
\hline
\end{tabular}

In our study, the ileum was the most common part of bowel involved. [63.63\%] [Refer Table No. 14]. In 2 cases, caecum was involved.

\section{DISCUSSION}

Siebold (1825), ${ }^{1}$ Simpson (1838) ${ }^{2}$ and Zilher (1883) ${ }^{3}$ were the first few who reported cases suspected to have necrotising enterocolitis.

First survival of neonates following surgical repair of NEC is credited to Agerty ${ }^{4}$ in 1943 . Bell ${ }^{5}$ published a severity based classification in 1978 which was modified by Walsh and Kliegem ${ }^{6}$ in 1986. 


\begin{tabular}{|l|l|}
\hline \multicolumn{1}{|c|}{ Bell's Stage 1 } & \multicolumn{1}{c|}{ Bell's stage 2 } \\
\hline $\begin{array}{l}\text { Mild symptoms and signs such as } \\
\text { apnoea, bradycardia, increased } \\
\text { gastric residuals and mild }\end{array}$ & $\begin{array}{l}\text { All signs and symptoms of stage I } \\
\text { with absent bowel sounds and } \\
\text { abdominal distension. } \\
\text { Radiological findings are } \\
\text { nonspecific. }\end{array}$ \\
$\begin{array}{l}\text { Treatment is mainly conservative } \\
\text { (nil per orally/IV antibiotics). }\end{array}$ & $\begin{array}{l}\text { Radiographs show presence of } \\
\text { portal venous gas with or } \\
\text { without ascites. } \\
\text { Treatment is mainly } \\
\text { conservative (nil per orally, } \\
\text { nasogastric aspiration, IV } \\
\text { antibiotics for prolonged } \\
\text { duration). }\end{array}$ \\
&
\end{tabular}

\section{Bell's Classification}

Necrotising enterocolitis frequently affects premature and low birth weight infants although full-term infants are also not immune to these conditions.

The aetiology appears multifactorial which include birth asphyxia, umbilical catheterisation, exchange transfusion, congenital heart disease, drug abuse and high osmolar feed. Necrotising enterocolitis frequently involves single or multiple segments of terminal ileum and colon.

Necrotising enterocolitis has an overall mortality of 25$30 \%$ which can further increase due to associated comorbid conditions such as low birth weight, prematurity and poor immunological status. Clinical picture of this condition is characterised by abdominal distension, vomiting, intolerance of food, blood in stool or frank intestine obstruction. Diagnosis is made usually on the basis of clinical features, radiological findings and investigations. Leucopenia and low platelet count with elevated IL-6 and TNF-alpha are diagnostic. Changes in level of C-reactive protein may be observed.

Stools may have evidence of occult or frank blood. Radiological examination may show pneumoperitoneum and ground glass appearance. Gas filled multiple bowel loop in centre of abdomen is the earliest and most common radiological finding in necrotising enterocolitis. Subsequent development of pneumatosis intestinalis will confirm the diagnosis. Ultrasonography of abdomen can pick up portal vein gas which may not be evident on plain radiograph.

Necrotising enterocolitis is a condition which requires close monitoring and continuation of medical treatment till patients develop complications which need immediate surgical interventions. Medical management consists of nasogastric aspiration, intravenous hydration with broad spectrum antibiotics. There are different complications of necrotising enterocolitis which require surgery. The most important indication for surgery is pneumoperitoneum. Relative indications of surgery are fixed bowel loops on serial radiographs, erythema of abdominal wall and positive paracentesis. Surgical procedures like peritoneal drainage, resection \& anastomosis of gangrene segment, resection \& enterostomy are performed. Patients of necrotising enterocolitis may develop complications either due to surgical procedure or during course of conservative treatment as a sequel of these conditions namely colonic and small bowel stricture, malabsorption, growth failure, short bowel syndrome, enteric fistula, cholestatic jaundice and liver failure.

This prospective study of necrotising enterocolitis was conducted in the Department of Surgery, M.G.M. Medical College \& M. Y. Hospital from May 2004 to Oct. 2006.
In our study, 11 (55\%) out of 20 cases presented at age between $3^{\text {rd }}$ to $12^{\text {th }}$ postnatal day. [Refer Table No. 1]. Eight patients had early onset of disease (PND $<2$ days), out of which 4 were term and remaining 4 were preterm. The premature babies have late presentation usually in $2^{\text {nd }}$ week. Similar results were obtained by Asindi et al $^{11}$ and Niyaz, ${ }^{8}$ Evelyn H.Dykes, ${ }^{9}$ Christopher cardot ${ }^{10}$ Franklin J Harberg. ${ }^{11}$

In our study, the male and female ratio (55:45) was 1.22:1, which was suggestive of an equal predisposition. [Refer Table No. 2]. Similar results were found in the study done by Grosfield et al ${ }^{12}$ Joao Carlos, ${ }^{13}$ Wilson R,14 Andreana butter. 15

Prematurity is the most important risk factor in the causation of NEC. Premature infants have higher chances of developing of NEC than full-term infant. In our study, $80 \%$ of patients of NEC were premature. Number of studies on this topic had reported significantly higher incidence of NEC in premature infants. ${ }^{7,8.9,12,13,16,17}$ NEC in premature infants has higher morbidity and mortality due to poor immunological status leading to increased susceptibility to systemic infection.

Gestational age at presentation has a bearing on the outcome and overall mortality of necrotising enterocolitis.

In our study, 11 patients of NEC were of extremely low birth weight. [55\%]. While 5 patients were of low birth weight [25\%] and only 4 patients were of birth weight more than $2 \mathrm{~kg}$ [20\%]. Similar results were obtained in the study by Asindi et $\mathrm{al}^{7}$ In our study; we found that NEC predominantly occurs in low birth weight infants, presumably due to immature gut mucosa and poor immunological status. Similar results were obtained in the study by Grosfield 12 and Niyaz. ${ }^{8}$

We observed that $18(90 \%)$ patients were delivered by normal vaginal delivery while two $(10 \%)$ were by Caesarean section. [Refer Table No. 5]. Gut mucosa injury can be initiated by variety of clinical factors like birth hypoxia. Similar results were obtained in the study by Grosfield, ${ }^{12}$ Niyaz. ${ }^{8}$ The lower prevalence of NEC in neonates who were delivered by Caesarean section indicates that management of high risk conditions and prevention of hypoxia at delivery could be important in prevention of NEC. Similar results were seen in other studies. ${ }^{18,19}$

We observed that enteral feeding was given to 19 (95\%) patients, 16 were breast-fed and 3 were top fed. [Refer Table no. 6]. Intraluminal nutrients may act as a substrate for bacterial overgrowth and promotes invasiveness in presence of mucosal injury. Similar results were obtained in the study by Michael B Marchildon. ${ }^{20}$ Birth asphyxia is found in 4 (20\%) out 20 patients. 20,21 
The clinical presentations of patients of NEC were studied. We observed that all the patients of NEC presented with complaint of abdominal distension. [Refer Table no. 8]. Half $(50 \%)$ of the total patients had melaena. Similar results were found by Grosfield, ${ }^{12}$ Niyaz $^{8}$ and Echevarria et al 22 Eighteen (90\%) patients had history of poor feeding. Other presenting complaints were vomiting, regurgitation and arrest of motion/flatus.

The clinical abdominal signs of patients were recorded in our study. The most frequent signs was distention of abdomen which was observed in all patients (100\%). Other clinical signs were tenderness [85\%], rigidity [70\%], guarding [70\%], visible veins over the anterior abdominal wall [10\%] and anterior abdominal wall erythema [25\%]. [Refer table No. 9]. Similar results were obtained in study done by Niyaz, ${ }^{8}$ Grosfield,12 Narang et al ${ }^{17}$ Hamish Hwang ${ }^{23}$ Christopher Cardot. ${ }^{10}$ About $35 \%$ patients had temperature instability in form of hypothermia. Similar results were obtained by Niyaz ${ }^{8}$ Hamish Hwang, ${ }^{23}$ Christopher Cardot. 10

Seventeen out of 20 Patients (85\%) had raised C reactive Protein. [Refer Table no. 10] Similar results were obtained by Pourcyrous M.24

In our study, x-ray of abdomen was done in all the cases. [Refer Table No. 11]. We observed that $40 \%$ of patients had finding of persistent dilated bowel loops in the consecutive $\mathrm{x}$ rays, $25 \%$ of patients had pneumatosis intestinalis [the most pathognomonic sign of NEC] and 35\% showed findings of pneumoperitoneum in their x-rays. Similar results were obtained by Grosfield ${ }^{12}$, Andreana Butter ${ }^{15}$ Hamish Hwang. ${ }^{23}$

In our study, out of the 20 diagnosed cases of NEC, 11 cases were operated. 2 cases were planned for surgery, but they succumbed before commencement of surgery.

The most common pathological finding was gangrenous bowel with ischaemia ( 5 cases) and in 4 cases there were perforations in the bowel. [Refer Table No.13]. Similar results were obtained by Grosfield, ${ }^{12}$ Alda L.Tom. ${ }^{25}$

Exploratory Laparotomy was the operation done in 11 patients those who were managed surgically. Gangrenous bowel was found on exploration in 5 patients, so resection of gangrenous bowel with stoma formation was done.

Perforation in the bowel was found in 4 patients. Among them, 2 patients were managed with resection of perforated segment with anastomosis, 1 patient with primary repair of perforation and stoma formation was done in one patient.

Oedematous bowel was the only finding in 1 patient, so only peritoneal lavage was done. In 1 patient, one stricture was found in the bowel that was smoothly passable, so the bowel was left undisturbed.

Thus, the main surgical procedure was enterostomy in our study that was done in total 6 patients [54.54\%]. Similar results were obtained in the study done by Grosfield, 12 Joao Carlos, ${ }^{13}$ Andreana Butter ${ }^{14}$ and W B Kiesewetter. ${ }^{26}$

In our study, the ileum was the most common part of bowel involved. [63.63\%] [Refer Table No. 14]. In 2 cases, caecum was involved. This area being more distal to the origin of the superior mesenteric artery has less blood supply and with hypoxic insult further increases the hypoxia and tissue damage. Similar results were obtained in the study done by Grosfield, ${ }^{12}$ Niyaz $^{8}$ Kurschied T. ${ }^{27}$

\section{CONCLUSION}

NEC is the most common gastrointestinal emergency in the neonates. In western world, various research project has been carried out, but in our country not so many studies have been done for the NEC. So this study was carried out in Maharaja Yashwant Rao Hospital, Indore. The following conclusions were made from the study. NEC is a disease of preterm babies as their gastrointestinal tract being immature. Low birth weight is also a causative factor in the NEC. The full-term infants had early onset of NEC. This is due to earlier enteral feeding and rapid progression of feeding. Hypoxic or haemodynamic instability results in splanchnic vasoconstriction and reduced mesenteric flow inducing mucosal hypoxia and rendering the intestine susceptible to injury. High incidence in neonates who were delivered through vaginal delivery indicates that management of high risk conditions and prevention of hypoxic stress at delivery could be important in prevention of NEC. The ileocaecal region is the most common part involved as this area is being more distal to the origin of the superior mesenteric artery and has less blood supply. Since most of our cases had severe disease with multiple risk factors like prematurity, low birth weight, hypothermia, and complications like DIC, thrombocytopenia and renal failure etc, resulting in the high mortality rate. Similar results were obtained in the study done by Odita JC. ${ }^{28}$ Our study is a modest attempt to identify and analyse various factors affecting neonatal NEC and the results of our study paves the way for further research on this topic.

\section{REFERENCES}

1. Siebold JF. Gerburtshulfe, Frauenziemmer Und, Kinderkranheiten Heft I. Leipzig necrotizing enterocolitis in the neonates.1825;5:3.

2. Simpson JY. Peritonitis in the fetus in uterus. Edinburgh Med Surg J 1838;15:390-414.

3. Zilner E. Ruptura flexurae sigmoidis neonati inter partum. Arch Path Anat 1884;96(2):307-18.

4. Agerty HA, Ziserman AJ, Shollenberger CL. A case of perforation of the ileum in a newborn infant with operation and recovery. J Pediatric 1943;22(2):233-8.

5. Bell MJ, Ternberg JL, Feigin RD, et al. Neonatal necrotizing enterocolitis. Therapeutic decisions based upon clinical staging. Ann Surg 1978;187(1):1-7.

6. Kliegman RM, Walsh MC. Neonatal necrotizing enterocolitis: pathogenesis, classification and spectrum of illness. Current Problems in Pediatrics 1987;17(4):21988.

7. Asindi A, Malhotra RK, Al Malki T, et al. Necrotizing enterocolitis in Saudi Arabia: experience in a referral neonatal intensive care unit. Annals of Saudi Medicine 1999;19(6):561-4.

8. Niyaz A, Buch MD, Ahmed M, et al. Neonatal necrotizing enterocolitis: a clinical study and outcome. JKPractitioner 2001;8(4);237-9.

9. Dykes EH, Gilmour WH, Azmy AF. Prediction of outcome following necrotizing enterocolitis in a neonatal surgical unit. J Pediatr Surg 1985;20(1):3-5.

10. Chardot C, Rochet JS, Lezeau H, et al. Surgical necrotizing enterocolitis: are intestinal lesions more severe in infants with low birth weight? J Pediatr Surg 2003;38(2):167-72. 
11. Harberg FJ, McGill CW, Saleem MM, et al. Resection with primary anastomosis for necrotizing enterocolitis. J Pediatr Surg 1983;18(6):743-6.

12. Grosfield JL, Cheu H, West KW, et al. Changing trends in necrotizing enterocolitis. Experience with 302 cases in two decades. Ann Surg 1991;214(3):301-7.

13. de Souza JC, da Motta UI, Ketzer CR. Prognostic factors of mortality in newborn with necrotizing enterocolitis submitted to exploratory laparotomy. J Pediatr Surg 2001;36(3):482-6.

14. Wilson R, Kanto WP, McCarthy BJ, et al. Age at onset of necrotizing enterocolitis. Risk factors in small infants. Am J Dis Child 1982;136(9):814-6.

15. Butter A, Flageole H, Laberge JM. The changing face of surgical indications for necrotizing enterocolitis. J Pediatr Surg 2002;37(3):496-9.

16. Ostlie DJ, Spilde TL, St Peter SD, et al. Necrotizing enterocolitis in full-term infants. J Pediatr Surg 2003;38(7):1039-42.

17. Narang A, Rao $R$, Bhakoo ON. Neonatal necrotizing enterocolitis an epidemiological study. Indian Pediatr 1993;30(10):1207-14.

18. Bottom SF, Paul RH, Iams JD, et al. Obstetric determinants of neonatal survival: influence of willingness to perform Caesarean delivery on survival of extremely low-birthweight infants. National institute of child health and human development network of maternal-fetal medicine units. Am J Obstet Gynecol 1997;176(5):960-6.

19. Uauy RD, Fanaroff AA, Korones SB, et al. Necrotizing enterocolitis in very low birth weight infants: biodemographic and clinical correlates. National institute of child health and human development neonatal research network. J Pediatric 1991:119(4):630-8.
20. Marchildon MB, Buck BE, Abdeour G. Necrotizing enterocolitis in the unfed infant. J Pediatr Surg 1982;17(5):620-4.

21. Andrews DA, Sawin RS, Ledbetter DJ. Necrotizing enterocolitis in term neonates. Am J Surg 1990;159(5):507-9.

22. Echevarria Ybarguengoitia JL, Ruelas Orozco GJ, Jasso Gutierezz L. Blood in the feces as an aid to diagnosis of necrotizing enterocolitis. Bol Med Hosp infant Mex 1981;38(5);771-6.

23. Hwang H, Murphy JJ, Gow KW, et al. Are localized intestinal perforation distinct from necrotizing enterocolitis? J Pediatr Surg 2003;38(5):763-7.

24. Pourcyrous M, Bada HS, Korones SB. Significances of serial C-reactive protein response in neonatal infections and other disorders. Pediatrics 1993;92(3):431-5.

25. Tam AL, Camberos A, Applebaum H. Surgical decision making in necrotizing enterocolitis and focal intestinal perforation: predictive value of radiologic findings. J Pediatric Surg 2002;37(12):1688-91.

26. Kiesewetter WB, Taghizadeh F, Bower RJ. Nectotizing enterocolitis: is there a place for resection and primary anastomosis? J Pediatr Surg 1979;14(3):360-3.

27. Kurscheid T, Holschneider AM. Necrotizing enterocolitis (NEC)--mortality and long-term result. Eur J Pediatr Surg 1993;3(3):139-43.

28. Odita JC, Omene JA. The clinical and radiological evaluation of neonatal necrotizing enterocolitis in Benin city, Nigeria. Trop Gregor Med 1979;31(3):347-52. 